\title{
Integrated Nutrient and Weed-Management Practices on Productivity and Profitability in Wheat (Triticum aestivum L.)
}

\author{
Dinesh Kumar $^{1 *}$, Vivek$^{2}$, Satendra Kumar ${ }^{3}$ and Virendra Kumar ${ }^{4}$ \\ ${ }^{1}$ Department of Agriculture, Govt. of Uttar Pradesh \\ ${ }^{2}$ Department of Agronomy, \\ ${ }^{3}$ Department of Soil Science and Agricultural Chemistry, Sardar Vallabhbhai Patel University \\ of Agriculture and Technology, Meerut, Uttar Pradesh-250 110, India \\ ${ }^{4}$ Department of Agronomy, Dolphin (P.G.) Institute of Biomedical and Natural Sciences, \\ Dehradun, Uttarakhand, India \\ *Corresponding author
}

\section{A B S T R A C T}

\section{Keywords}

Farmyard manure, Productivity, Profitability, Herbicides, Nutrient uptake, Wheat

Article Info

\section{Accepted:}

26 January 2021

Available Online:

10 February 2021
A field experiment was conducted during 2009-10 and 2010-11 at Meerut, Uttar Pradesh, to study the effect of different herbicides and nutrient management practices on weeds and productivity of wheat (Triticum aestivum L.). In this experiment, 4 nutrient levels viz.; control (No NPK), 50\% NPK + FYM 15 t /ha, $75 \%$ NPK + FYM $10 \mathrm{t} / \mathrm{ha}$ and $100 \% \mathrm{NPK}$ and 5 weed control measures viz.; Pendimethalin $1.0 \mathrm{~kg} / \mathrm{ha}$, Fenoxaprop + metsulfuron-methyl $(100+4 \mathrm{~g} / \mathrm{ha})$, Fenoxaprop + carfentrazone (100 $+10 \mathrm{~g} / \mathrm{ha}$ ), two hand weeding ( 25 \& $45 \mathrm{DAS}$ ) and weedy check. Combined application of $75 \%$ NPK and farmyard manure $10 \mathrm{t}$ /ha significantly improved wheat yield and soil nutrient status. The highest grain and straw yields were recorded with application of $75 \%$ NPK + FYM $10 \mathrm{t} / \mathrm{ha}$, which was at par with $100 \%$ NPK. Farmyard manure acts as a nutrient reservoir and releases nutrients slowly expected to be more closely matched with supply and demand by the crop. Among the weed control treatments gave significantly higher grain yield compared to weedy check. The highest grain yield were obtained from two hand weeding treatment, although this remained statistically at par with Fenoxaprop + carfentrazone $(100+10 \mathrm{~g} / \mathrm{ha})$ and both the treatments resulted in an increase of grain yield as compared to weedy check respectively. The highest net returns and benefit:cost ratio were obtained with application Fenoxaprop + carfentrazone $(100+10 \mathrm{~g} / \mathrm{ha})$ among the tested herbicide treatments.

\section{Introduction}

Wheat is one of the world's most widely cultivated food crops. It contributes $40 \%$ in the total food grain production in the country, next to rice. It is grown in 29.1 million ha in India with the production of 102.2 million tonnes and productivity of 3.51 tonnes/ha 
(MoF, 2019). The wheat productivity greatly depends on availability of nutrients and moisture, besides the climatic factors.

It is an excellent health-building food containing approximately $78 \%$ carbohydrates, $11-12 \%$ protein, $2 \%$ fat and minerals each and considerable amount of vitamins (Kumar et al., 2011). Integrated use of organic manures and fertilizers not only helps in maintaining the highest productivity but also provides stability in crop production. However, one of the demerits of use of organic manures is that they may carry weed seeds which results not only in weed infestation but also introduces new weed species. The interactive advantages of combining organic and inorganic sources of nutrients in integrated nutrient management have shown additive effect in comparison to the use of each component separately.

Besides, organic manures also supply the traces of micronutrients which are not supplied by chemical fertilizers. Therefore, it is needed to compare various organic manures with chemical fertilizers to find out the most effective combinations. The integrated nutrient management (INM) system envisages use of organic manures and biofertilizers with inorganic nutrient sources. Farmyard manure (FYM) is an important organic resource for agricultural production in livestock based farming systems in many countries including semi-arid regions of India (Motavalli et al., 1994). Organic amendments like farmyard manure (FYM) may play a major role in supplementing the crop nutrients through their direct addition, improvement in soil condition, nitrogen fixation and solubilisation of fixed forms of phosphorus and zinc in soil. Farmyard manure is widely used as organic nutrient source but due to declining number of farm animals with mechanization and increasing area under cultivation only a small quantity of FYM per ha is available (Chavan et al., 2014). Plant nutrients can be supplied from different sources, viz. organic manures, crop residues, chemical fertilizers and biofertilizers. For better utilization of resources and to produce crops with less expenditure, integrated nutrient management is the best approach. The integrated approach of nutrient supply by using organic, inorganic and biofertilizers is gaining importance, because this system not only reduces the use of costly inorganic fertilizers, but also it is an ecofriendly approach.

Among the several causes of low productivity in Uttar Pradesh, increasing population of canary grass (Phalaris minor Retz.) with broad leaf weeds causing substantial yield loss in wheat. Yield reduction due to weeds is 38$42 \%$ (Bharat and Kachroo, 2007) or even more. Anjuman and Bajwa (2010) reported that selected wheat varieties incurred 60-75\% biomass loss due to weed infestation. With the introduction of high- yielding dwarf varieties having heavy demand of inputs, the problem of weed infestation has increased manifold, as it created favourable condition for invasion as well as luxuriant growth of weeds, particularly Phalaris minor. Weeds infestation in wheat is rampant and caused depletion of $31 \mathrm{~kg} \mathrm{~N}, 16$ $\mathrm{kg} \mathrm{P}$ and $29 \mathrm{~kg} \mathrm{~K} / \mathrm{ha}$ from wheat crop field (Pandey et al., 2007) and considerable amount of secondary and micronutrients, thereby resulting in heavy yield reduction. Commonly used herbicides isoproturon and sulfosulfuron control grassy weeds only but had little effect on troublesome broad-leaf weeds. Further, continuous use of isoproturon caused development of resistant biotypes of Phalaris minor (Malik and Singh, 1995). To overcome these problem farmers are applying more nutrients and different brands of herbicides alone or in combination to eliminate the weeds, but such practices lack proper scientific evidences. Hence it is essential to identify alternate herbicide molecules with broad-spectrum activity or their combination of available herbicides for sustainable weed 
management in wheat. Since weeding in India is commonly done by manually; unavailability of labor at critical time and higher cost, herbicides are considered to be an alternative to hand-weeding. Keeping these facts in view, the present investigation was carried to evaluate the influence of different integrated nutrient and weed-management practices on productivity and profitability in wheat.

\section{Materials and Methods}

The field experiment was conducted during 2009-10 and 2010-11 at Crop Research Centre of the Sardar Vallabhbhai Patel University of Agriculture and Technology, Modipuram, Meerut $\left(29^{\circ} 05^{\prime} 19^{\prime \prime} \mathrm{N}\right.$ and $77^{\circ}$ 41' 50"E), Uttar Pradesh. The soil of the experimental field was sandy loam in reaction $(p \mathrm{H} \mathrm{7.60),} \mathrm{low} \mathrm{in} \mathrm{organic} \mathrm{carbon}(0.43 \%)$, available nitrogen (245 kg N/ha), and medium in available phosphorus (13.0 $\mathrm{kg} \mathrm{P} / \mathrm{ha}$ ) and potassium (185 kg K/ha). Treatments were laid down in a factorial randomized block design, replicated thrice with 2 factors. First factor consisted of 5 weed control measures, viz. Pendimethalin $1.0 \mathrm{~kg} / \mathrm{ha}$, Fenoxaprop + metsulfuron-methyl $(100+4 \mathrm{~g} / \mathrm{ha})$, Fenoxaprop + carfentrazone $(100+10 \mathrm{~g} / \mathrm{ha})$ and two hand weeding ( 25 \& 45 DAS) and weedy check and the second factors 4 nutrient levels control (No NPK), 50\% NPK + FYM $15 \mathrm{t} / \mathrm{ha}, 75 \% \mathrm{NPK}+\mathrm{FYM} 10 \mathrm{t} / \mathrm{ha}$ and $100 \%$ NPK. Wheat variety 'PBW 343' was sown on 28 November, 2010 and 29 November, 2011 with $100 \mathrm{~kg}$ seed/ha, keeping row-to-row distance of $20 \mathrm{~cm}$ during both the years of experimentation. Nitrogen was applied as per treatment, but full amount of $\mathrm{P}$ and $\mathrm{K}$ were applied at the time of sowing and FYM was applied as per treatments and incorporated into the soil before the sowing of the crop. As per treatments, all the post-emergence herbicides were dissolved in water and applied 35 days after sowing, whereas pendimethalin was applied as pre- emergence two day after sowing using knapsack sprayer fitted with flatfan nozzle. Total weed density and biomass of weeds were recorded 60 days after sowing (DAS) and at harvesting using a quadrat of 0.5 $\mathrm{m} \times 0.5 \mathrm{~m}$ randomly selected at 2 places in each plot. Furthermore, all weeds from quadrat were cut at the ground level, placed in a paper bag and dried for $48 \mathrm{hrs}$ in an oven at $70^{\circ} \mathrm{C}$ and then were weighed to determine the weed dry biomass. Grain yield recorded in $\mathrm{kg} /$ plot was finally converted into grain yield in $\mathrm{kg} / \mathrm{ha}$. Weed data (density and biomass) were subjected to square-root transformation $\sqrt{x}+1$. Weed-control efficiency was computed on the basis of total weed density at harvesting. Economics of wheat cultivation as influenced by organic manures, chemical fertilizer, herbicides and integrated nutrient management were calculated by considering the prevailing market price of wheat grain and straw and different input.

\section{Results and Discussion}

\section{Effect on weeds}

The major weed flora in the experimental field comprised grasses, viz. Phalaris minor and Avena ludoviciana; broad-leaf weeds, viz. Chenopodium album, Anagallis arvensis and Melilotus indica; and other weeds. Nutrient management treatments significantly reduced the density and dry weight of weeds as compared to control as per two years pooled data (Table 1). Density of Phalaris minor tended to decline with advancement in crop age irrespective of the treatments. The highest weed density was recorded with control application which declined with nutrient application. The reduction in weed density was highest with application of $75 \%$ NPK + FYM $10 \mathrm{t}$ /ha though it was at par with $100 \%$ NPK then 50\% NPK + FYM 15 t /ha. In case of dry matter accumulation, similar trends were found as density. The higher dry matter accumulation of weeds was under control and 
almost similar to $50 \%$ NPK + FYM $15 \mathrm{t} / \mathrm{ha}$ (Table 1). It may be due to lower density of crop plants and more competition of weed plants and crop. The dominance of Phalaris minor in the field suppressed the others weeds. Density of Chenopodium album, and others weed had significantly, maximum weed density and dry weight were found under control treatment followed by 50\% NPK + FYM $15 \mathrm{t} / \mathrm{ha}$ and $100 \%$ NPK. Application of $75 \%$ NPK + FYM 10 t /ha shifted the competitive advantage in favour of crop and also helped smothering the weeds. It appeared that vigorous crop stand and growth due to nutrient level asserted a strong smothering effect on growth and development of weeds (Patel et al., 2012).

Weed control efficiency was higher in $75 \%$ NPK + FYM 10 t /ha followed by $100 \%$ NPK and $50 \%$ NPK + FYM 15 t /ha at 60 days after sowing during both the years (Table 2). It may be due to higher soil compaction, lower germination of weeds, and vigorous growth of crop and suppression effect of crop plants on weeds. Sepat et al., (2010) also reported less weed density and dry matter accumulation under $75 \%$ NPK + FYM 10 t /ha as compared to $100 \%$ NPK.

Weed control measures had significant effect on weed population and its dry matter accumulation. The Fenoxaprop + carfentrazone $(100+10 \mathrm{~g} / \mathrm{ha})$ treatment was effective to control the weeds viz. Phalaris minor, Avena ludoviciana, Chenopodium album, Anagallis arvensis, Melilotus indica; and other weeds. In general weed density reduced after execution of weed control measures as the crop come in advance stage. Application of Fenoxaprop + carfentrazone $(100+10 \mathrm{~g} / \mathrm{ha})$, resulted significantly lower weed density and dry matter accumulation of weeds (Table 1). It was effective than Fenoxaprop + metsulfuron-methyl $(100+4$ $\mathrm{g} / \mathrm{ha}$ ) and Pendimethalin $1.0 \mathrm{~kg} / \mathrm{ha}$ to control weeds. Our results confirm the findings of Khan et al., (2017). The highest weed-control efficiency was also recorded under Fenoxaprop + carfentrazone $(100+10 \mathrm{~g} / \mathrm{ha})$ than Fenoxaprop + metsulfuron-methyl $(100+$ $4 \mathrm{~g} / \mathrm{ha}$ ), might be owing to lower weed density and dry weight production of weed which resulted successful checking of weed growth under this treatment.

\section{Yield attributes}

The important yield attributes of wheat, viz. spike length, number of grains per spike, number of spikelets per spike and 1000-grain weight (g) were significantly influenced by different treatments during both the years (Table 2). The spike length under $75 \%$ NPK + FYM 10 t /ha significantly higher than 50\% NPK + FYM $15 \mathrm{t}$ /ha and was found at par with $100 \%$ NPK, it was observed significantly superior to rest of the treatments during both the years. A part from $75 \%$ NPK + FYM $10 \mathrm{t}$ /ha, $100 \%$ NPK treatment was found next best performance, which showed its superiority over control for most of the yield attributes.

Superiority of $75 \%$ NPK + FYM 10 t /ha might be due to better plant growth. Such parameters were not favourable in control treatment, which were hurdle for initial growth and reflected by lower crop growth and development. Thus, it is evident that combined use of chemical fertilizers and farmyard manure favoured better plant growth parameters, which eventually reflected in improved values of yield attributes in our study. Our results confirm the findings of Rathor and Sharma (2010).

Yields attributes were affected significantly by weed control measures. Two hand weeding (25 \& 45 DAS) treatment had significantly higher spike length, number of grains per spike, number of spikelets per spike and 1000grain weight $(\mathrm{g})$ over rest of the treatments 
(Table 2). Amongst the herbicidal treatments, the spike length, number of grains per spike, number of spikelets per spike and 1000-grain weight (g) were recorded in ready-mix application of Fenoxaprop + carfentrazone $(100+10 \mathrm{~g} / \mathrm{ha})$, although this remained statistically at par with the herbicidal treatments, namely Fenoxaprop + metsulfuron-methyl $(100+4 \mathrm{~g} / \mathrm{ha})$ and Pendimethalin $1.0 \mathrm{~kg} / \mathrm{ha}$.

This might be owing to better performance of both combined application of herbicides in controlling grassy and broad-leaf weeds and therefore resulted in less weed-crop competition as compared to their alone application.

These results are in close conformity with those reported by Pal et al., (2016). Two hand weeding (25 \& 45 DAS) and ready-mix application of Fenoxaprop + carfentrazone $(100+10 \mathrm{~g} / \mathrm{ha})$ treatments recorded significantly effective spike length over weedy check, sole application of Pendimethalin 1.0 $\mathrm{kg} / \mathrm{ha}$ and ready-mix application of Fenoxaprop + metsulfuron-methyl $(100+4$ $\mathrm{g} / \mathrm{ha}$ ).

The maximum spike length, number of grains per spike, number of spike lets per spike and 1000-grain weight recorded with two hand weeding (25 \& 45 DAS) treatment which was comparable with Fenoxaprop + carfentrazone $(100+10 \mathrm{~g} / \mathrm{ha})$ treatment were significantly superior to all other herbicides.

The crop remained in advantage with the treatments and it completed its vegetative growth and development satisfactorily owing to favorable temperature condition which ultimately accumulated more dry matter and promoted the yield attributes favorably. Similar results were also obtained by Mehmood et al., (2014) and Rana et al., (2017).

\section{Yield}

The nutrient management treatments significantly influenced the grain yield of wheat during both the years (Table 2). The highest grain yield were recorded with application of $75 \%$ NPK + FYM $10 \mathrm{t} / \mathrm{ha}$, which was at par with $100 \%$ NPK than $50 \%$ NPK+ FYM 15 t/ha.

It indicates that addition of FYM with $75 \%$ NPK proved beneficial in increasing the grain yield of wheat over $100 \%$ NPK. Furthermore, addition of organic manures, viz. farm yard manure, with NPK was a better option for enhancing the grain yield of wheat. The harvest index was not influenced significantly by the application of nutrient management treatments during both the years.

Actually, the main difference existed in harvest index which caused significant changes in grain yield under different nutrient management treatments. The highest value of harvest index (\%) was recorded with $75 \%$ NPK + FYM $10 \mathrm{t}$ /ha fallowed 100\% NPK than $50 \%$ NPK+ FYM 15 t/ha. The beneficial effect of organic manures on grain yield and harvest index characters might be assigned to the fact that after proper decomposition and mineralization, these manures supplied available plant nutrients directly to the plants and also had solubilising effect on fixed forms of nutrients in soil. Mubarak and Singh (2011) and Singh et al., (2012) also reported similar findings.

The weed-control treatments had significant influenced on grain yield and harvest index. The highest grain yield and harvest index were obtained from two hand weeding ( 25 \& 45 DAS) treatment, although this remained statistically at par with Fenoxaprop + carfentrazone $(100+10 \mathrm{~g} / \mathrm{ha})$ and both the treatments, resulted in an increase grain yield as compared to weedy check. 
Table.1 Density and dry matter accumulation of different weeds at 60 days after sowing as influenced by integrated nutrient and weedmanagement practices in wheat (pooled data of 2 years)

\begin{tabular}{|c|c|c|c|c|c|c|c|c|c|c|c|c|}
\hline \multirow[t]{2}{*}{ Treatment } & \multicolumn{6}{|c|}{ Density of different weeds (No. per $\mathbf{m}^{2}$ ) } & \multicolumn{6}{|c|}{ Dry matter accumulation $\left(\mathrm{g} / \mathrm{m}^{-2}\right)$} \\
\hline & $\begin{array}{l}\text { Phalaris } \\
\text { minor }\end{array}$ & $\begin{array}{c}\text { Avena } \\
\text { ludovician } \\
\text { a }\end{array}$ & $\begin{array}{l}\text { Chenopodiu } \\
\text { m album }\end{array}$ & $\begin{array}{l}\text { Anagallis } \\
\text { arvensis }\end{array}$ & $\begin{array}{l}\text { Melilotus } \\
\text { indica }\end{array}$ & $\begin{array}{l}\text { Others } \\
\text { weeds }\end{array}$ & $\begin{array}{l}\text { Phalaris } \\
\text { minor }\end{array}$ & $\begin{array}{c}\text { Avena } \\
\text { ludovician } \\
\text { a }\end{array}$ & $\begin{array}{l}\text { Chenopodiu } \\
\text { m album }\end{array}$ & $\begin{array}{c}\text { Anagallis } \\
\text { arvensis }\end{array}$ & $\begin{array}{l}\text { Melilotus } \\
\text { indica }\end{array}$ & $\begin{array}{l}\text { Others } \\
\text { weeds }\end{array}$ \\
\hline \multicolumn{13}{|c|}{ Nutrient management } \\
\hline Control & $\begin{array}{c}4.68 \\
(22.54)\end{array}$ & $\begin{array}{c}4.49 \\
(20.53)\end{array}$ & $\begin{array}{c}4.13 \\
(17.20)\end{array}$ & $\begin{array}{c}3.82 \\
(15.07)\end{array}$ & $\begin{array}{c}3.52 \\
(12.80)\end{array}$ & $\begin{array}{c}3.24 \\
(10.79)\end{array}$ & $\begin{array}{c}3.57 \\
(12.43)\end{array}$ & $\begin{array}{c}3.43 \\
(11.41)\end{array}$ & $\begin{array}{c}3.22 \\
(10.17)\end{array}$ & $\begin{array}{c}3.20 \\
(10.09)\end{array}$ & $\begin{array}{c}3.06 \\
(9.20)\end{array}$ & $\begin{array}{c}2.99 \\
(8.85)\end{array}$ \\
\hline $\begin{array}{c}50 \% \text { NPK+ FYM } 15 \\
\text { t/ha }\end{array}$ & $\begin{array}{c}4.46 \\
(20.53)\end{array}$ & $\begin{array}{c}4.24 \\
(18.54)\end{array}$ & $\begin{array}{c}3.87 \\
(15.73)\end{array}$ & $\begin{array}{c}3.59 \\
(13.33)\end{array}$ & $\begin{array}{c}3.29 \\
(11.20)\end{array}$ & $\begin{array}{c}3.02 \\
(9.33)\end{array}$ & $\begin{array}{c}3.44 \\
(11.61)\end{array}$ & $\begin{array}{c}3.28 \\
(10.51)\end{array}$ & $\begin{array}{c}3.09 \\
(9.46)\end{array}$ & $\begin{array}{c}3.06 \\
(9.28)\end{array}$ & $\begin{array}{c}2.90 \\
(8.31)\end{array}$ & $\begin{array}{c}2.82 \\
(7.88)\end{array}$ \\
\hline$\underset{\text { t/ha }}{75 \% \text { NPK + FYM } 10}$ & $\begin{array}{c}4.01 \\
(16.53)\end{array}$ & $\begin{array}{c}3.59 \\
(13.47)\end{array}$ & $\begin{array}{c}3.43 \\
(12.67)\end{array}$ & $\begin{array}{c}3.12 \\
(10.40)\end{array}$ & $\begin{array}{c}2.64 \\
(7.60)\end{array}$ & $\begin{array}{c}2.46 \\
(6.66)\end{array}$ & $\begin{array}{c}3.13 \\
(9.54)\end{array}$ & $\begin{array}{c}2.82 \\
(7.74)\end{array}$ & $\begin{array}{c}2.79 \\
(7.71)\end{array}$ & $\begin{array}{c}2.70 \\
(7.27)\end{array}$ & $\begin{array}{c}2.37 \\
(5.67)\end{array}$ & $\begin{array}{c}2.36 \\
(5.68)\end{array}$ \\
\hline $100 \%$ NPK & $\begin{array}{c}4.25 \\
(18.53)\end{array}$ & $\begin{array}{c}4.01 \\
(16.53)\end{array}$ & $\begin{array}{c}3.68 \\
(14.27)\end{array}$ & $\begin{array}{c}3.38 \\
(12.00)\end{array}$ & $\begin{array}{c}2.98 \\
(9.33)\end{array}$ & $\begin{array}{c}2.76 \\
(8.00)\end{array}$ & $\begin{array}{c}3.30 \\
(10.68)\end{array}$ & $\begin{array}{c}3.13 \\
(9.50)\end{array}$ & $\begin{array}{c}2.93 \\
(8.68)\end{array}$ & $\begin{array}{c}2.90 \\
(8.35)\end{array}$ & $\begin{array}{c}2.65 \\
(6.96)\end{array}$ & $\begin{array}{c}2.61 \\
(6.80)\end{array}$ \\
\hline $\operatorname{SEm}( \pm)$ & 0.11 & 0.13 & 0.12 & 0.13 & 0.12 & 0.11 & 0.06 & 0.05 & 0.06 & 0.04 & 0.05 & 0.23 \\
\hline C.D. $(P=0.05)$ & 0.36 & 0.37 & 0.36 & 0.38 & 0.35 & 0.34 & 0.18 & 0.17 & 0.16 & 0.15 & 0.16 & 0.15 \\
\hline \multicolumn{13}{|c|}{ Weed control practices } \\
\hline $\begin{array}{c}\text { Pendimethalin } 1.0 \\
\text { kg/ha }\end{array}$ & $\begin{array}{c}4.61 \\
(20.50)\end{array}$ & $\begin{array}{c}4.24 \\
(17.33)\end{array}$ & $\begin{array}{c}3.92 \\
(14.83)\end{array}$ & $\begin{array}{c}3.60 \\
(12.17)\end{array}$ & $\begin{array}{c}3.15 \\
(9.17)\end{array}$ & $\begin{array}{c}2.97 \\
(8.00)\end{array}$ & $\begin{array}{c}3.55 \\
(11.65)\end{array}$ & $\begin{array}{c}3.28 \\
(9.90)\end{array}$ & $\begin{array}{c}3.13 \\
(8.92) \\
\end{array}$ & $\begin{array}{c}3.05 \\
(8.41) \\
\end{array}$ & $\begin{array}{c}2.77 \\
(6.78) \\
\end{array}$ & $\begin{array}{c}2.77 \\
(6.74)\end{array}$ \\
\hline $\begin{array}{c}\text { Fenoxaprop + } \\
\text { metsulfuron-methyl } \\
100+4.0 \mathrm{~g} / \mathrm{ha}\end{array}$ & $\begin{array}{c}4.26 \\
(17.50)\end{array}$ & $\begin{array}{c}3.99 \\
(15.33)\end{array}$ & $\begin{array}{c}3.75 \\
(13.49)\end{array}$ & $\begin{array}{c}3.39 \\
(1.83)\end{array}$ & $\begin{array}{c}2.98 \\
(8.17)\end{array}$ & $\begin{array}{c}2.73 \\
(6.67)\end{array}$ & $\begin{array}{c}3.30 \\
(9.98)\end{array}$ & $\begin{array}{c}3.10 \\
(8.75)\end{array}$ & $\begin{array}{c}2.99 \\
(8.11)\end{array}$ & $\begin{array}{c}2.89 \\
(7.47)\end{array}$ & $\begin{array}{c}2.63 \\
(6.06)\end{array}$ & $\begin{array}{c}2.55 \\
(5.62)\end{array}$ \\
\hline $\begin{array}{c}\text { Fenoxaprop + } \\
\text { carfentrazone } 100 \\
+\mathbf{1 0 . 0} \text { g/ha }\end{array}$ & $\begin{array}{c}3.89 \\
(14.50)\end{array}$ & $\begin{array}{c}3.64 \\
(12.66)\end{array}$ & $\begin{array}{c}3.38 \\
(10.83)\end{array}$ & $\begin{array}{c}3.03 \\
(8.50)\end{array}$ & $\begin{array}{c}2.54 \\
(5.83)\end{array}$ & $\begin{array}{c}2.16 \\
(4.00)\end{array}$ & $\begin{array}{c}3.04 \\
(8.25)\end{array}$ & $\begin{array}{c}2.84 \\
(7.22)\end{array}$ & $\begin{array}{c}2.70 \\
(6.50)\end{array}$ & $\begin{array}{c}2.60 \\
(5.88)\end{array}$ & $\begin{array}{c}2.26 \\
(4.30)\end{array}$ & $\begin{array}{c}2.05 \\
(3.35)\end{array}$ \\
\hline $\begin{array}{l}\text { Two hand weeding } \\
\text { (25\&45 DAS) }\end{array}$ & $\begin{array}{c}2.73 \\
(6.67) \\
\end{array}$ & $\begin{array}{c}2.57 \\
(5.99) \\
\end{array}$ & $\begin{array}{c}2.07 \\
(3.58) \\
\end{array}$ & $\begin{array}{c}1.91 \\
(3.00) \\
\end{array}$ & $\begin{array}{c}1.75 \\
(2.50) \\
\end{array}$ & $\begin{array}{c}1.67 \\
(2.17) \\
\end{array}$ & $\begin{array}{c}2.19 \\
(3.88) \\
\end{array}$ & $\begin{array}{c}2.06 \\
(3.41) \\
\end{array}$ & $\begin{array}{c}1.75 \\
(2.14) \\
\end{array}$ & $\begin{array}{c}1.73 \\
(2.07) \\
\end{array}$ & $\begin{array}{c}1.64 \\
(1.84) \\
\end{array}$ & $\begin{array}{c}1.64 \\
(1.81) \\
\end{array}$ \\
\hline Weedy check & $\begin{array}{c}6.26 \\
(38.50)\end{array}$ & $\begin{array}{c}5.97 \\
(34.99)\end{array}$ & $\begin{array}{c}5.75 \\
(32.49)\end{array}$ & $\begin{array}{c}5.46 \\
(29.17)\end{array}$ & $\begin{array}{c}5.11 \\
(25.50)\end{array}$ & $\begin{array}{c}4.83 \\
(22.67)\end{array}$ & $\begin{array}{c}4.73 \\
(21.48)\end{array}$ & $\begin{array}{c}4.54 \\
(19.68)\end{array}$ & $\begin{array}{c}4.50 \\
(19.35)\end{array}$ & $\begin{array}{c}4.56 \\
(19.91)\end{array}$ & $\begin{array}{c}4.42 \\
(18.72)\end{array}$ & $\begin{array}{c}4.46 \\
(18.99)\end{array}$ \\
\hline $\operatorname{SEm}( \pm)$ & 0.14 & 0.13 & 0.14 & 0.14 & 0.13 & 0.12 & 0.07 & 0.07 & 0.06 & 0.05 & 0.06 & 0.06 \\
\hline C.D. $(P=0.05)$ & 0.42 & 0.41 & 0.40 & 0.42 & 0.39 & 0.38 & 0.20 & 0.19 & 0.18 & 0.17 & 0.18 & 0.17 \\
\hline
\end{tabular}

Original values is parentheses and data subjected to square root $(\sqrt{x}+1)$ transformation 
Table.2 Weed control efficiency, yield attributes, grain yield and economics as influenced by integrated nutrient and weed-management practices in wheat (pooled data of 2 years)

\begin{tabular}{|c|c|c|c|c|c|c|c|c|c|}
\hline Treatment & $\begin{array}{c}\text { Weed } \\
\text { control } \\
\text { efficiency } \\
\text { at } 60 \text { days }\end{array}$ & $\begin{array}{c}\text { Spike } \\
\text { length } \\
\text { (cm) }\end{array}$ & $\begin{array}{c}\text { No. of } \\
\text { grains/ } \\
\text { spike }\end{array}$ & $\begin{array}{c}\text { No of } \\
\text { spikelets/ } \\
\text { spike }\end{array}$ & $\begin{array}{c}\text { 1000- } \\
\text { Grain } \\
\text { weight (g) }\end{array}$ & $\begin{array}{l}\text { Grain } \\
\text { yield t/ha }\end{array}$ & $\begin{array}{c}\text { Harvest } \\
\text { index } \\
(\%)\end{array}$ & $\begin{array}{l}\text { Net returns } \\
\left(\mathrm{Rs} \times \mathbf{1 0}^{\mathbf{3}} / \mathrm{ha}\right)\end{array}$ & $\begin{array}{c}\text { Benefit: } \\
\text { cost } \\
\text { ratio }\end{array}$ \\
\hline \multicolumn{10}{|c|}{ Nutrient management } \\
\hline Control & 52.06 & 8.7 & 34.5 & 10.2 & 37.2 & 2.75 & 39.4 & 20.73 & 1.07 \\
\hline $50 \%$ NPK+ FYM 15 t/ha & 54.35 & 9.8 & 39.1 & 11.8 & 40.3 & 4.49 & 39.5 & 40.21 & 1.57 \\
\hline 75\% NPK + FYM 10 t/ha & 58.49 & 10.9 & 43.4 & 14.7 & 42.6 & 4.75 & 39.8 & 42.82 & 1.63 \\
\hline $100 \%$ NPK & 55.54 & 10.4 & 41.6 & 13.5 & 41.5 & 4.65 & 39.6 & 41.83 & 1.61 \\
\hline $\operatorname{SEm}( \pm)$ & - & 0.24 & 0.52 & 0.21 & 0.39 & 0.05 & 0.13 & - & - \\
\hline C.D. $(P=0.05)$ & - & 0.72 & 1.51 & 0.62 & 1.14 & 0.15 & NS & - & - \\
\hline \multicolumn{10}{|c|}{ Weed control practices } \\
\hline Pendimethalin 1.0 kg/ha & 55.95 & 9.7 & 38.4 & 11.6 & 39.5 & 4.20 & 39.4 & 38.04 & 1.59 \\
\hline $\begin{array}{c}\text { Fenoxaprop + metsulfuron- } \\
\text { methyl } 100+4.0 \mathrm{~g} / \mathrm{ha}\end{array}$ & 61.45 & 10.0 & 39.5 & 12.3 & 40.4 & 4.37 & 39.6 & 39.76 & 1.63 \\
\hline $\begin{array}{l}\text { Fenoxaprop + carfentrazone } \\
\qquad 100+10.0 \mathrm{~g} / \mathrm{ha}\end{array}$ & 70.09 & 10.2 & 41.5 & 13.4 & 41.2 & 4.53 & 39.7 & 41.75 & 1.70 \\
\hline $\begin{array}{c}\text { Two hand weeding }(25 \& 45 \\
\text { DAS })\end{array}$ & 87.47 & 10.7 & 42.6 & 14.5 & 42.3 & 4.64 & 39.8 & 39.32 & 1.38 \\
\hline Weedy check & 0 & 9.3 & 36.1 & 10.8 & 38.4 & 3.07 & 39.2 & 23.09 & 1.06 \\
\hline $\operatorname{SEm}( \pm)$ & - & 0.26 & 0.57 & 0.24 & 0.45 & 0.05 & 0.15 & - & - \\
\hline C.D. $(P=0.05)$ & - & 0.80 & 1.68 & 0.70 & 1.27 & 0.16 & 0.36 & - & - \\
\hline
\end{tabular}


Table.3 Effect of integrated nutrient and weed management practices on nutrient uptake of wheat (pooled data of 2 years)

\begin{tabular}{|c|c|c|c|}
\hline \multirow[t]{2}{*}{ Treatment } & \multicolumn{3}{|c|}{ Total uptake (kg/ha) } \\
\hline & Nitrogen & Phosphorus & Potassium \\
\hline \multicolumn{4}{|c|}{ Nutrient management } \\
\hline Control & 62.74 & 13.19 & 72.58 \\
\hline $50 \% \mathrm{NPK}+\mathrm{FYM} 15 \mathrm{t} / \mathrm{ha}$ & 115.70 & 23.97 & 134.28 \\
\hline $75 \% \mathrm{NPK}+\mathrm{FYM} 10 \mathrm{t} / \mathrm{ha}$ & 131.30 & 28.15 & 147.55 \\
\hline $100 \%$ NPK & 122.53 & 26.12 & 141.50 \\
\hline $\operatorname{SEm}( \pm)$ & 0.48 & 0.25 & 0.46 \\
\hline C.D. $(P=0.05)$ & 1.37 & 0.72 & 1.34 \\
\hline \multicolumn{4}{|c|}{ Weed control practices } \\
\hline Pendimethalin $1.0 \mathrm{~kg} / \mathrm{ha}$ & 107.005 & 21.94 & 124.03 \\
\hline $\begin{array}{l}\text { Fenoxaprop + metsulfuron-methyl } 100+ \\
4.0 \mathrm{~g} / \mathrm{ha}\end{array}$ & 112.98 & 23.76 & 129.76 \\
\hline $\begin{array}{c}\text { Fenoxaprop + carfentrazone } 100+10.0 \\
\text { g/ha }\end{array}$ & 119.32 & 25.67 & 135.64 \\
\hline Two hand weeding (25\&45 DAS) & 124.53 & 27.03 & 140.65 \\
\hline Weedy check & 76.49 & 15.87 & 89.79 \\
\hline $\operatorname{SEm}( \pm)$ & 0.53 & 0.28 & 0.48 \\
\hline C.D. $(P=0.05)$ & 1.54 & 0.81 & 1.40 \\
\hline
\end{tabular}

It is all because of the fact that both the treatments showed its superiority in most of the yield attributes as well as these results might be because difference in weed dry weight obtained due to weed-control treatments, which resulted in reduced crop competition for space, solar radiation interceptions, moisture and nutrient uptake. The results confirmed the findings of Pal et al., (2016). The application of Fenoxaprop + metsulfuron-methyl $(100+4 \mathrm{~g} / \mathrm{ha})$ and Pendimethalin $1.0 \mathrm{~kg} / \mathrm{ha}$ remained at par with each other. It is obvious that dry matter is net saving of photosynthesis and essential for the building up of plant organs, which ultimately reflect on biomass production. Similar results were found by Singh et al., (2015).

\section{Nutrient uptake}

The difference in total nutrient uptake (NPK) by the crop under different nutrient management was noticed in the present study (Table 3). Total uptake of N, P and K in wheat grain and straw was increased significantly with the nutrient management treatment $(75 \%$ $\mathrm{NPK}+\mathrm{FYM} 10 \mathrm{t} / \mathrm{ha}$ ), while a significant decline in nutrient uptake was observed under the weedy check. The low uptake of these nutrients under control treatment may be attributed to less plant biomass. Sinebo et al., (2004) also reported that nutrients uptake was higher at lower dose of nutrients application (75 \% NPK + FYM 10 t /ha) but drastically decreased with a further increase in the rate of the nutrient uptake. However, application of nitrogen in 3 splits coinciding with crop requirements might have reduced rapid mineralization and losses through different pathways and thereby increased nutrient contents in wheat grain and straw that resulted in increased biomass of wheat plant owing to higher uptake of $\mathrm{N}, \mathrm{P}$ and $\mathrm{K}$. Weed management practices significantly reduces 
NPK uptake by weeds and enhanced nutrient uptake by the crop. Among weed management treatments, highest nutrient uptake was recorded in two hand weeding (25 \& 45 DAS) treatment after was recorded in application of Fenoxaprop + carfentrazone $(100+10 \mathrm{~g} / \mathrm{ha})$.

This herbicide treatment was superior to all other treatments with respect to weed control during both the years, increased the availability of nutrients by minimizing cropweed competition and resulted in more drymatter accumulation in the crop, which was ultimately reflected in more nutrient uptake. Our findings are similar to the results reported by Chopra et al., (2008) and Kien et al., (2016).

\section{Economics}

Economics reveals that highest net returns as well as benefit: cost ratio was found under the application of $75 \%$ NPK + FYM $10 \mathrm{t} / \mathrm{ha}$, followed by $100 \% \mathrm{NPK}$ and $50 \% \mathrm{NPK}+\mathrm{FYM}$ $15 \mathrm{t} /$ ha (Table 2). Even application of organic manures (FYM) with 75\% NPK proved much better over $100 \%$ NPK alone, particularly with respect to the net returns and benefit: cost ratio.

Among the weed-control treatments, the highest net returns and benefit: cost ratio were obtained from the application of Fenoxaprop + carfentrazone $(100+10 \mathrm{~g} / \mathrm{ha})$, followed by Fenoxaprop + metsulfuron-methyl $(100+4$ $\mathrm{g} / \mathrm{ha}$ ) and two hand weeding (25 \& 45 DAS). Alone application of herbicides also accured higher net returned than weedy check. Unweeded plots gave the lowest monetary returns in both the years due to poor crop yields (Beenrajee et al., 2019). Carfentrazone was compatible with fenoxaprop as tank mixture and there was no adverse effect on efficacy of both the herbicides against complex weed flora in wheat. Fenoxaprop + carfentrazone $(100+10 \mathrm{~g} / \mathrm{ha})$ as the best combination for achieving maximum weed control efficacy and satisfactory grain yields. These findings are in close vicinity with those reported by Singh et al., (2018).

Among the methods of weed control, Fenoxaprop + carfentrazone $(100+10 \mathrm{~g} / \mathrm{ha})$ gave excellent control of weeds population and increased the yield attributes and yield, gross returns, net returns and $\mathrm{B}: \mathrm{C}$ ratio. Application of $75 \% \mathrm{NPK}+\mathrm{FYM} 10 \mathrm{t} / \mathrm{ha}$ in combination with Fenoxaprop + carfentrazone $(100+10 \mathrm{~g} / \mathrm{ha})$ was found effective to manage weeds and increase wheat grain yield.

\section{References}

Anjuman, T. and Bajwa, R. 2010. Competition losses caused by Rumex dentatus L. and Chenopodium album L. In wheat (Triticum aestivum L.). The Philippine Agricultural Scientist 93 (3): September.

Banerjee, H., Garai, S., Sarkar, S., Ghosh, D., Samanta, D. and Mahato, M. 2019. Efficacy of herbicides against canary grass and wild oat in wheat and their residual effects on succeeding greengram in coastal Bengal. Indian Journal of Weed Science 51(3): 246251.

Bharat, R. and Kachroo, D. 2007. Bio-efficacy of various herbicides and their mixture on weeds and yield of wheat (Triticum aestivum) under subtropical agroecosystem. Indian Journal of Agronomy 52(1): 53-59.

Chavan, A.P., Jain, N.K. and Mahadkar, U.V. 2014. Direct and residual effect of fertilizers and biofertilizers on yield, nutrient uptake and economics of groundnut-rice cropping system. Indian Journal of Agronomy 59(1): 53-58.

Chopra, N.K., Chopra, N. and Singh, H.P. 2008. Assessment of nutrient uptake 
by weeds and crop and its subsequent effect on grain quality in wheat. Indian Journal of Agricultural Sciences 78(6): 540-542.

Khan, N., Chaudhry, S., Siddiqui, M.Z., Yadav, R.A. and Husain, K. 2017. Effect of weed management options and nitrogen scheduling on weed dynamics and yield of wheat (Triticum aestivum L.) under central plain zone of Uttar Pradesh. Indian Journal of Agronomy 62(4): 464-469.

Kien, P.T., Massey, J.X., Mundra, S.L. and Kalita, S. 2016. Effect of weed management practices on productivity of wheat.Indian Journal of Weed Science 48(4): 445-446.

Kumar, P., Yadav, R.K., Gollen, B., Kumar, S., Verma, R.K. and Yadav, S. 2011. Nutritional contents and medicinal properties of wheat: A review. Life Sciences and Medicinal Research 47(2): 145-149.

Malik, R.K. and Singh, S. 1995. Little seed canary grass (Phalaris minor) resistance to isoproturon in India. Weed Technology 9: 419-25.

Mehmood, Zia, Ashiq, Muhammad, Noorka, Ijaz Rasool, Ali, Amjed, Tabasum, Saba and Iqbal, Muhammad Shahid. 2014. Chemical control of monocot weeds in wheat (Triticum aestivum L.). American Journal of Plant Sciences 5(9): 5 pages DOI:10.4236/ajps.59140.

MoF, 2019. Economic Survey 2019-20. (In) Statistical Tables, Selected Indicators 1990-91 to 2018-19. Ministry of Finance, Government of India.

Motavalli, P.P., Singh, R.P. and Anders, M.M. 1994. Perception and management of farmyard manure in the semiarid tropics of India. Agricultural Systems 46(2): 189-204.

Mubarak, T. and Singh, K.N. 2011. Nutrient management and productivity of wheat (Triticum aestivum) based cropping system in temperate zone. Indian Journal of Agronomy 56 (3): 176-181.

Pal, S., Sharma, R., Sharma, H.B. and Singh, R. 2016. Influence of different herbicides on weed control, nutrient removal and yield of wheat (Triticum aestivum L.). Indian Journal of Agronomy 61(1): 59-63.

Pandey, I.B., Dwivedi, D.K. and Pandey, R.K. 2007. Efficacy of herbicides and fertilizer management on weeds dynamics in wheat (Triticum aestivum L.). Indian Journal of Agronomy 52(1): 49-52.

Patel, S.M., Patel, J.C., Chaudhary, P.P., Patel, D.M., Patel, G.N. and Patel, B.M. 2012. Effects of nitrogen levels and weed management on production potential of weed (Triticum aestivam L.). Research on Crops 13(2) : 456462

Rana, L., Banerjee, H., Ray, K. and Sarkar, S. 2017. System of wheat intensification (SWI) - A new approach for increasing wheat yield in small holder farming system. Journal of Applied and Natural Science 9(3): 1,4531,464 .

Rathor, S.A. and Sharma, N.L. 2010. Effect of integrated nutrient management on productivity and nutrient uptake in wheat and soil fertility. Asian Journal of Soil Science 4(2): 208-210.

Sepat, R.N., Rai, R.K. and Dhar, S. 2010. Planting systems and integrated nutrient management for enhanced wheat (Triticum aestivum) productivity. Indian Journal of Agronomy 55 (2): 114-118.

Sinebo, W., Gretzmacher, R. and Edelbauer, A. 2004. Genotypic variation for nitrogen use efficient in Ethiopian barley. Field Crops Research 85(1): 43-60.

Singh, A.P., Pandagare, T., Abrahum, S., Chandrakar, D. and Chowdhury, T. 
2015. Evaluation of metribuzin in combination with clodinafop, sulfosulfuron and Pinoxaden for weed control in wheat. International Journal of Life Science 10(1): 271-274.

Singh, J.P., Kaur, J., Mehta, D.S. and Narwal, R.P. 2012. Long-term effect of nutrient management on soil health and crop productivity under rice-wheat cropping system. Indian Journal of Fertilisers 8(8): 28-48.

Singh, S.P., Yadav, R.S., Kumawat, A. and Bairwa, R.C. 2018. Weed control in greengram (Vigna radiata) and its residual effect on Indian mustard (Brassica juncea). Indian Journal of Agronomy 63(1): 21-25.

\section{How to cite this article:}

Dinesh Kumar, Vivek, Satendra Kumar and Virendra Kumar. 2021. Integrated Nutrient and Weed-Management Practices on Productivity and Profitability in Wheat (Triticum aestivum L.). Int.J.Curr.Microbiol.App.Sci. 10(02): 3433-3443. doi: https://doi.org/10.20546/ijcmas.2021.1002.379 